\title{
Understanding the Natural Role of Stem Cells in the Body: A New Understanding of Disease Formation?
}

\section{Christian Drapeau*}

Stemtech International, 151 Calle Iglesia, San Clemente, CA 92672, USA

Few fields of science have known such a rapid and global development as what has been seen in stem cell research over the past decade, with a growing number of quality publications such as this Journal. Promises of cures have fueled research at all levels, by a vast number of scientific and clinical teams worldwide. The general approach includes isolation [1-3], proliferation [4], pre-conditioning [5-7], and then injection either in an artery, a vein, or in the tissue itself. However, given the fact that the vast majority of stem cell treatments available in various clinics worldwide merely consist in injecting stem cells in the bloodstream without pre-conditioning, thereby simply increasing the number of circulating stem cells, one question remains conspicuously absent from the stem cell discussion: what is the natural role of endogenous stem cells?

Growing literature points to the fact that endogenous stem cells essentially constitute the natural repair system of the body. A few hours after acute myocardial infarction (AMI), the cardiac tissue releases G-CSF [8], a known stem cell mobilizer. As its concentration slowly increases in the bloodstream, G-CSF triggers the mobilization of bone marrow stem cells, increasing the number of peripheral blood stem cells which peaks at around 4-7 days after AMI [8]. The same phenomenon has been documented after skin burn [9], bone fracture [10] and stroke [11]. Then following a signal from the affected tissue, circulating stem cells migrate in the tissue where they differentiate in cells of that tissue, participating to the process of tissue repair [12].

However, there is an inherent bias in medical research; we study diseases, rarely health, so this is a phenomenon that has been essentially documented as part of an effort to study potential treatments to debilitating diseases. Yet, a number of studies have revealed that this phenomenon also takes place to a lesser extent, day to day, without the presence of an injury. These observations have essentially come from studies or human treatments involving sex-mismatch organ or bone marrow transplants. For example, Krause et al. [13] reported that 11 months after injection of male stem cells in female mice, Y-chromosome bearing cells were found in various tissues including the liver, muscle, skin, lung, and intestine.

In humans, cardiomyocytes of extracardiac origin have been identified in hearts of patients undergoing sex-mismatched cardiac transplantation [14]. Similar observations have been made in women after sex-mismatch bone marrow transplant, showing a positive relationship between chimerism in the heart and length of time after transplant, without cardiac injury, suggesting a steady-state recruitment of marrow progenitor cells rather than an initial seeding event early after transplantation [15]. In the absence of tissue injury, after sex-mismatch bone marrow transplant, biopsy specimens from all female recipients showed chimerism that reached as high as $5 \%$ in the liver after 13 days, $2 \%$ in the skin after 19 days, and $6 \%$ in the gastrointestinal tract after 60 days [16].

It has been estimated that a normal person loses annually approximately 7 million cardiomyocytes and yet the number of cardiac cells remains relatively stable from childhood to adulthood, we can therefore conclude that approximately $15 \%$ of the heart has been renewed when a healthy adult reaches 40 years of age. Similar estimates have been obtained by Bergman et al. [17] who quantified C14 in the DNA of human cardiomyocytes. C14 concentrations in the atmosphere increased sharply after the beginning of above-ground nuclear bomb tests and then dropped exponentially after the Limited Nuclear Test Ban Treaty of 1963, with atmospheric C14 levels being well documented. Since carbon is incorporated in the DNA at the time of cellular division, the concentration of C14 in DNA can be used retrospectively to date the birth of human cells. Using this approach, Bergman et al. concluded that it takes roughly 25 years to renew about half the human heart.

Although data is not available in humans, it has been reported in mice that up to $3 \%$ of new insulin-producing pancreatic $\beta$ cells are formed every few days [18]. Other studies suggested that the liver renews itself at a rate of approximately $0.16 \%$ per day [19] and the lung at $0.07 \%$ per day [13]. Therefore, in theory, we would have on average a new pancreas and a new liver every few years, new lung every 4 years, as well as significant renewal of the heart and brain over one's lifetime [20].

The current data does not allow for the precise determination of each organ's turnover rate, nevertheless this simple observation brings forth a novel understanding of disease formation. While the general understanding is that most degenerative diseases result from the loss of a specific type of cells (pancreatic $\beta$-cells for diabetes, dopaminergic neurons in Parkinson's disease, cone cells in macular degeneration, pneumocytes in the lung, etc.), we can see that a healthy 40 year old adult may have lost and replaced his liver more than 10 times, his pancreas and lung more than 8 times, and yet this person is still healthy without diabetes, liver failure or COPD. Therefore, the loss of cells is not the cause of disease formation; diseases result from a decline in the ability to self-renew which overtime leads to an overall cellular deficit in a tissue. Health is a balance between cellular loss and tissue renewal and diseases develop when the rate of cellular loss exceeds the rate of stem cell-based tissue renewal.

This view is supported by a number of recent studies linking the development of various degenerative diseases with a lower number of circulating stem cells. For example, a linear relationship has been documented between the number of circulating stem cells and the various phases of diabetes development, namely impaired fasting

*Corresponding author: Christian Drapeau, MSc, Stemtech International, 151 Calle Iglesia, San Clemente, 92672, USA, Tel: 949-542-8600; Fax: 949-542-8617; E-mail: cdrapeau@stemtechmail.com

Received July 22, 2013; Accepted July 23, 2013; Published July 25, 2013

Citation: Drapeau C (2013) Understanding the Natural Role of Stem Cells in the Body: A New Understanding of Disease Formation? J Stem Cell Res Ther 3: e116. doi:10.4172/2157-7633.1000e116

Copyright: (c) 2013 Drapeau C. This is an open-access article distributed under the terms of the Creative Commons Attribution License, which permits unrestricted use, distribution, and reproduction in any medium, provided the original author and source are credited. 
glucose, impaired glucose tolerance and insulin-dependent diabetes [21]. Similar observations have been made with cardiovascular diseases [22], atherosclerosis [23], Alzheimer's disease [24], rheumatoid arthritis [25], pulmonary diseases [26], erectile dysfunction [27], and muscular dystrophy [28].

Therefore, it appears that a decline or failure of endogenous repair might be the underlying cause for the development of various degenerative diseases, and consequently supporting endogenous repair by enhancing stem cell mobilization, circulation and migration into tissues could constitute a novel approach in healthcare.

\section{References}

1. Can A, Balci D (2011) Isolation, Culture, and Characterization of Human Umbilical Cord Stroma-derived Mesenchymal Stem Cells. Methods Mol Biol 698: 51-62.

2. Zachar V, Rasmussen JG, Fink T (2011) Isolation and growth of adipose tissue-derived stem cells. Methods Mol Biol 698: 37-49.

3. Gronthos S, Arthur A, Bartold PM, Shi S (2011) A method to isolate and culture expand human dental pulp stem cells. Methods Mol Biol 698: 107-121.

4. Ivanovic Z, Duchez P, Chevaleyre J, Vlaski M, Lafarge X, et al. (2011) Clinicalscale cultures of cord blood CD34+ cells to amplify committed progenitors and maintain stem cell activity. Cell Transplant 20: 1453-1463.

5. Greco SJ, Zhou C, Ye JH, Rameshwar P (2008) A method to generate human mesenchymal stem cell-derived neurons which express and are excited by multiple neurotransmitters. Biol Proced Online 10: 90-101.

6. Behfar A, Faustino RS, Arrell DK, Dzeja PP, Perez-Terzic C, et al. (2008) Guided stem cell cardiopoiesis: discovery and translation. J Mol Cell Cardiol 45: 523-529.

7. Snykers S, De Kock J, Tamara V, Rogiers V (2011) Hepatic differentiation of mesenchymal stem cells: in vitro strategies. Methods Mol Biol 698: 305-314.

8. Leone AM, Rutella S, Bonanno G, Contemi AM, de Ritis DG, et al. (2006) Endogenous G-CSF and CD34+ cell mobilization after acute myocardial infarction. Int J Cardiol 111: 202-208.

9. Fox A, Smythe J, Fisher N, Tyler MP, McGrouther DA, et al. (2008) Mobilization of endothelial progenitor cells into the circulation in burned patients. $\mathrm{Br} \mathrm{J}$ Surg 95: 244-251.

10. Lee DY, Cho TJ, Kim JA, Lee HR, Yoo WJ, et al. (2008) Mobilization of endothelial progenitor cells in fracture healing and distraction osteogenesis. Bone 42: 932-941.

11. Hennemann B, Ickenstein G, Sauerbruch S, Luecke K, Haas S, et al. (2008) Mobilization of CD34+ hematopoietic cells, colony-forming cells and longterm culture-initiating cells into the peripheral blood of patients with an acute cerebral ischemic insult. Cytotherapy 10: 303-311.

12. Drapeau C, Eufemio G, Mazzoni P, Roth GD, Stranberg S (2012) The therapeutic potential of stimulating endogenous stem cell mobilization. In:
Tissue Regeneration, GW Yip (Ed) Yong Loo Lin School of Medicine, National University of Singapore, Singapore 167-202.

13. Krause DS, Theise ND, Collector MI, Henegariu O, Hwang S, et al. (2001) Multi-organ, multi-lineage engraftment by a single bone marrow-derived stem cell. Cell 105: 369-377.

14. Müller P, Pfeiffer P, Koglin J, Schäfers HJ, Seeland U, et al. (2002) Cardiomyocytes of noncardiac origin in myocardial biopsies of human transplanted hearts. Circulation106: 31-35.

15. Deb A, Wang S, Skelding KA, Miller D, Simper D, et al. (2003) Bone MarrowDerived Cardiomyocytes Are Present in Adult Human Heart: A Study of Gender-Mismatched Bone Marrow Transplantation Patients. Circulation 107 1247-1249.

16. Körbling M, Katz RL, Khanna A, Ruifrok AC, Rondon G, et al. (2002) Hepatocytes and epithelial cells of donor origin in recipients of peripheral-blood stem cells. N Engl J Med 346: 738-746.

17. Bergmann O, Bhardwaj RD, Bernard S, Zdunek S, Barnabé-Heider F, et al (2009) Evidence for cardiomyocyte renewal in humans. Science 324: 98-102.

18. Bonner-Weir S (2000) beta-cell turnover: its assessment and implications. Diabetes 1: S20-4.

19. Theise ND, Nimmakayalu M, Gardner R, Illei PB, Morgan G, et al. (2000) Liver from bone marrow in humans. Hepatology 32: 11-16.

20. Biebl M, Cooper CM, Winkler J, Kuhn HG (2000) Analysis of neurogenesis and programmed cell death reveals a self-renewing capacity in the adult rat brain. Neurosci Lett 291: 17-20.

21. Fadini GP, Boscaro E, de Kreutzenberg S, Agostini C, Seeger F, et al. (2010) Time course and mechanisms of circulating progenitor cell reduction in the natural history of type 2 diabetes. Diabetes Care 33: 1097-1102.

22. Werner N, Kosiol S, Schiegl T, Ahlers P, Walenta K, et al. (2005) Circulating endothelial progenitor cells and cardiovascular outcomes. N Engl J Med 353: 999-1007.

23. Zenovich AG, Taylor DA (2008) Atherosclerosis as a disease of failed endogenous repair. Front Biosci 13: 3621-3636.

24. Lee ST, Chu K, Jung KH, Park HK, Kim DH, et al. (2009) Reduced circulating angiogenic cells in Alzheimer disease. Neurology 72: 1858-1863.

25. Grisar J, Aletaha D, Steiner CW, Kapral T, Steiner S, et al. (2005) Depletion of endothelial progenitor cells in the peripheral blood of patients with rheumatoid arthritis. Circulation 111: 204-211.

26. Palange P, Testa U, Huertas A, Calabrò L, Antonucci R, et al. (2006) Circulating haemopoietic and endothelial progenitor cells are decreased in COPD. Eu Respir J 27: 529-541.

27. Foresta C, Caretta N, Lana A, Cabrelle A, Palù G, et al. (2005) Circulating endothelial progenitor cells in subjects with erectile dysfunction. Int J Impot Res 17: 288-290.

28. Marchesi C, Belicchi M, Meregalli M, Farini A, Cattaneo A, et al. (2008) Correlation of circulating CD133+ progenitor subclasses with a mild phenotype in Duchenne muscular dystrophy patients. PLoS One 3: e2218. 